\title{
ВПЛИВ ЄВРОІНТЕГРАЦІЙНИХ ПРОЦЕСІВ НА МОДЕРНІЗАЦІЮ ФОРМ І ЗМІСТУ ПІДГОТОВКИ РЕЗЕРВУ ДИРЕКТОРІВ ШКІЛ
}

\author{
Клокар Н. І. д. п. н., професор. \\ Україна, м. Київ, ДВНЗ «Університет менеджменту освіти» \\ НАПН України
}

DOI: https://doi.org/10.31435/rsglobal_ws/30082018/6073

\section{ARTICLE INFO}

Received: 26 July 2018

Accepted: 25 August 2018

Published: 30 August 2018

\section{KEYWORDS}

integration processes, changes,

future school principals, preparation, school leadership,

best European practices.

\begin{abstract}
The article deals with the problem of influence European integration processes on future school principals’ preparation in Ukraine. The results of experimental research shows the importance of modernization of Ukrainian education system, demonstrate the necessity of changes in theory \& practice of school leadership. Preparation of future school principals is one of the main tasks for local authorities \& it should be based on the best European practices.
\end{abstract}

Citation: Клокар Н. I. (2018) Vplyv Yevrointehratsiinykh Protsesiv na Modernizatsiiu Form i Zmistu Pidhotovky Rezervu Dyrektoriv Shkil. World Science. 8(36), Vol.3. doi: 10.31435/rsglobal_ws/30082018/6073

Copyright: (C) 2018 Клокар Н. I. This is an open-access article distributed under the terms of the Creative Commons Attribution License (CC BY). The use, distribution or reproduction in other forums is permitted, provided the original author(s) or licensor are credited and that the original publication in this journal is cited, in accordance with accepted academic practice. No use, distribution or reproduction is permitted which does not comply with these terms.

Вступ. Питання підготовки резерву керівників закладів освіти, зокрема директорів шкіл, набуває особливої ваги в контексті суспільно - політичних і соціально - економічних змін у державі, що суттєво впливають на стратегію розвитку освіти країни, їі входження у європейський освітній простір.

Упродовж останніх років Україна пройшла нелегкий шлях, щоб подолати глибоко вкорінену корупцію, зробити діяльність державного сектора прозорішою та зменшити ризики для фінансової стабільності й економічних зловживань:

- набирають сили євроінтеграційні процеси. У першу чергу - громадяни України офіційно отримали можливість безвізового перетину кордону з країнами Європи, які входять до Шенгенської зони;

- здійснюються економічні реформи, що проявляється у прагненні зламати стару корупційну систему і вийти на такий економічний і соціальний рівень, який відповідав би західним та європейським нормам, реалізації низки завдань з метою покращення середовища для ведення бізнесу, розкриття потенціалу ринку землі та підтримка інвестицій, що сприятиме економічному зростанню;

- суттєвими є проведені заходи з антикорупційної реформи: запуск та інституалізація ProZorro - системи публічних електронних закупівель, що встановила новий стандарт прозорості та підзвітності держави; запуск системи електронної подачі декларацій, за допомогою якої посадовці зобов'язані декларувати свої статки; створення нових органів для розслідування та покарання випадків корупції серед високопосадовців (НАБУ і САП);

- розпочата й успішно проводиться децентралізація влади, що передбачає передачу повноважень та фінансів від державної влади якнайближче до людей - органам місцевого самоврядування. Завдяки прийнятому законодавству, в основі якого Європейська хартія 
місцевого самоврядування, місцева влада отримала розширені повноваження і можливість самостійно стягувати податки;

- активізувався процес розвитку громадянського суспільства. Одним із головних показників зміцнення такого устрою є розуміння громадянами особистої відповідальності за розвиток економічного, політичного, соціального устрою держави. Сьогодні все більша кількість населення України усвідомлює, що саме їм, громадянам, об’єднаним на рівні місцевих громад, належить вирішальна роль у забезпеченні якості свого життя.

Важливу роль у реалізації завдань, що стоять перед громадами відіграють директори шкіл.

Результати дослідження. Адміністративна реформа, розвиток громадянського суспільства, збільшений перелік повноважень, що передаються на місця, актуалізували проблему кадрового забезпечення змін, готовності керівників муніципальних служб і закладів використовувати сучасні технології управління 3 метою забезпечення якості життя громадян. Трансформаційні зміни у розвитку держави стали поштовхом і для суттєвих зрушень у освіті та знайшли своє відображення у нових Законах України «Про освіту», «Про вищу освіту», Концепції Нової української школи, проектах Законів «Про професійну освіту», «Про загальну середню освіту», «Про освіту дорослих». Успішне вирішення проблеми забезпечення доступності і якості освіти жителів громад $є$ у прямій залежності від рівня сформованості професійних компетентностей директорів шкіл.

Аналіз останніх досліджень і публікацій у галузі педагогіки, психології, філософії освіти, управління освітою, загальноосвітніми навчальними закладами показує, що вітчизняними вченими (В. Андрущенко, О. Боднар, Л. Ващенко, В. Гладкова, Л. Даниленко, Г. Дмитренко, Г. Сльникова, І. Зязюн, С. Калашнікова, Л. Калініна, Л. Карамушка, О. Касьянова, Н. Клокар, В. Кремень, В. Крижко, Т. Лукіна, В. Лунячек, В. Маслов, В. Олійник, $\begin{array}{llll}\text { C. Пазиніч, } & \text { О. Пастовенський, } & \text { В. Пікельна, } & \text { В. Приходько, Н. Протасова, Б. Ренькас, }\end{array}$ Л. Сергеєва, Т. Сорочан, Г. Тимошко та ін.) проводиться різнопланове дослідження широкого кола питань професійної діяльності керівників навчальних закладів. Питання системних змін і підготовки лідерів суспільних трансформацій є одним із головних напрямів пошуку багатьох зарубіжних дослідників (Б. Адамс, М. Армстронг, У. Байхем, Р. Бланкен, Н. Брінгман, Ч. Веббер, Дж. Голд, Д. Кеттнекер, М. Ламсон, А. Лєвін, Санг Мін Лі, П. Лоранж, А. Мамфорд, М. Мескон, Б. Мулфорд, Санні М. Мюллер, Д. Ноттер, І. Оплатка, У. Портер, Дж. Равен, К. Роджерс, М. Фуллан та ін.), що підтверджує актуальність проблеми підготовки сучасних керівників. Разом $з$ тим, проблема підготовки резерву управлінських кадрів для галузі освіти, зокрема директорів шкіл, в умовах сучасних викликів і суспільних трансформацій в Україні, модернізації системи освіти, імплементації основних положень Закону України «Про освіту», концепції Нової української школи (НУШ) залишається нерозв’язаною i потребує обгрунтування. Існує реальна потреба у підготовці керівників шкіл, здатних задовольняти запити місцевої громади на якісну освіту, в т. ч. створення умов для пожиттєвого навчання дорослих. Для влади на місцях робота 3 резервом керівників шкіл (підбір, оцінювання претендентів, навчання і призначення на посади) може стати дієвим засобом реалізації завдання забезпечення якості життя населення.

Мета і завдання наукового пошуку полягає у розкритті сутності процесу формування i підготовки резерву керівників загальноосвітніх навчальних закладів в умовах системних перетворень, що базуються на результатах експериментальних досліджень, обгрунтуванні сучасних форм і змісту такої підготовки і враховують трансформаційні зміни, які мають місце у державі. Здійснений нами науковий пошук проблеми підготовки резерву директорів шкіл 21-го ст. показав, що для вирішення поставлених завдань важливим $є$ врахування здобутків європейських дослідників у розвитку освітнього лідерства та кращого європейського досвіду підготовки директорів шкіл. Щонайперше, така робота повинна базуватися на використанні концептуальних засад педагогіки 21-го ст., що грунтується на ключових принципах дидактики i вибудовує технологічні, інформаційні й медіавпливи, навчає контекстуально, є міждисциплінарною, будується на співпраці, використовує проектне навчання, прийоми і методи проблемного навчання, здійснює прозоре оцінювання, розвиває навички критичного мислення [1]. Основою професійного розвитку майбутнього керівника школи має бути неперервне навчання як ключова складова філософії освіти нового століття. Ідея безперервної освіти, на думку основоположника андрагогіки як науки М. Ноулза, міститься у психосоціальній характеристиці дорослої людини. Головною ознакою дорослої людини він вважає іiі прагнення до задоволення своїх потреб. На вершині цих потреб - потреба у самоактуалізації чи у прояві всіх їі потенційних можливостей. Це прагнення і $є$ тією природною основою, що спонукає дорослу людину до процесу самоосвіти протягом усього життя [2]. У першій декаді нового століття і 
на зламі тисячоліть, є спільне сприйняття того, що лідери освіти повинні проходити спеціальну підготовку для того, щоб вони змогли задавати тон у освітніх трендах [3].

Для обгрунтування концептуальних засад підготовки резерву директорів шкіл, формуванні переліку складових управлінських компетентностей керівника, що вивчалися у процесі наукового пошуку (Табл.), використовувалися напрацьовані нами матеріали 3 питань навчання і професійного розвитку керівників галузі освіти [4-7], проаналізована низка праць зарубіжних дослідників і практиків. Зокрема враховувалися результати порівняльних досліджень щодо навичок 21-го ст., представлених у роботі канадських дослідників «Компетентності 21-го століття» [8], запропоновані Р. Бланкеном сучасні підходи до лідерства: харизматичний, інноваційний, авторитарний i контролюючий, ситуативний, ліберальний, прискорювач, служитель, трансформаційний [9], визначення ключових можливостей керівника закладу освіти 21-го ст, які подає експерт з інновацій Гарвардського університету Т. Вагнер: здатність до інновацій, вміння надихати інших, здатність впливати на зміни [10], проведений М. Ламсон аналіз сучасних трендів підготовки лідерів, у якому авторка зазначає, що найбільш актуальними є питання менеджменту і лідерства, технологічні навички і розвиток кар'єри [11], взаємопов'язані компоненти шкільного лідерства, запропоновані Б. Мулфордом у роботі «Виклики лідерства: покращення навчання у школах»: шкільний контент, шкільна організація, шкільне лідерство; успішної моделі управління школою [12], обгрунтування ролі самоосвіти у підготовці майбутніх шкільних лідерів та навчання для лідерства, які розглядають В. Фрік і А. Райлі [13], вісім якостей успішного лідера: візія, сміливість, професійний запал, емоційний інтелект, розсудливість, стійкість, переконаність, зацікавленість, які обгрунтовують кращі британські керівники шкіл [14], розуміння шкільної управлінської практики і транскультурної складової шкільного лідерства, що розкриваються у роботі П'єра Туловіцкі «Лідерство і вдосконалення школи у Франції» [15, с. 812-835], усвідомлення того, що успішне спілкування у школі залежить від відкритості, чесності, високого ступеня прозорості, вміння й здатності керівника слухати $[16$, с. 55-71], проведений А. Вокером, Х. Кян аналіз підготовки майбутніх директорів шкіл, що включає формальну підготовку керівників, комплектування, видачу ліцензій та соціалізацію [17, с. 297-309], роль віртуального професійного об'єднання, що дає можливість керівникам шкіл не лише обмінюватися знаннями, але й кращими управлінськими практиками для подальшого розвитку закладів освіти [18, с. 215-229], розширення можливостей навчання для служіння потребам громади та побудови мережі підтримки i партнерства, інноваційне лідерство, що забезпечить розроблення i впровадження нового куррикулуму і організації освітнього середовища, необхідності нових парадигм від керівників освіти [19, с. 187-198]. Заслуговує на увагу запропонований Д. Боттомз і К. О’Нілл підхід до розгляду двох ключових питань підготовки майбутнього директора школи: Що успішні освітянські лідери повинні знати і вміти? Як маємо готувати і розвивати ефективних шкільних лідерів? На думку авторів нове покоління директорів повинно мати глибоке розуміння шкільної і внутрішньокласної практики, що сприяє здобуткам учнів, знати як використовувати владу й інші впливи для моделювання й забезпечення постійного вдосконалення учнів, як здійснювати необхідну підтримку персоналу для забезпечення здорового мікроклімату школи, виконання навчального плану і завдань навчальної практики [20].

Таблиця 1. Рівні володіння директором школи управлінськими компетентностями сучасного керівника. Контрольні/експериментальні групи

\begin{tabular}{|c|l|c|c|c|c|c|}
\hline $\begin{array}{c}\text { № } \\
\text { п/п }\end{array}$ & \multicolumn{1}{|c|}{$\begin{array}{c}\text { Складові управлінських компетентностей } \\
\text { директора школи }\end{array}$} & $\begin{array}{c}\mathrm{B} \\
\%\end{array}$ & $\begin{array}{c}\mathrm{BC} \\
\%\end{array}$ & $\begin{array}{c}\mathrm{C} \\
\%\end{array}$ & $\begin{array}{c}\mathrm{HC} \\
\%\end{array}$ & $\begin{array}{c}\mathrm{H} \\
\%\end{array}$ \\
\hline 1 & \multicolumn{1}{|c|}{2} & 3 & 4 & 5 & 6 & 7 \\
\hline 1. & $\begin{array}{l}\text { Ефективне володіння усним і писемним } \\
\text { мовленням }\end{array}$ & $5 / 24$ & $48 / 62$ & $32 / 12$ & $13 / 2$ & $2 / 0$ \\
\hline 2. & Мотивація до кар'єрного розвитку & $-/ 13$ & $-/ 28$ & $55 / 44$ & $29 / 11$ & $16 / 4$ \\
\hline 3. & Здатність мотивувати інших & $2 / 15$ & $7 / 52$ & $52 / 16$ & $20 / 14$ & $19 / 3$ \\
\hline 4. & $\begin{array}{l}\text { Здатність створювати атмосферу довіри і } \\
\text { невимушеності у спілкуванні зі співрозмовниками }\end{array}$ & $-/ 5$ & $2 / 51$ & $46 / 33$ & $40 / 9$ & $12 / 2$ \\
\hline 5. & Критичне мислення & $3 / 15$ & $20 / 29$ & $28 / 36$ & $29 / 11$ & $20 / 9$ \\
\hline 6. & Здатність вирішувати проблеми & $1 / 14$ & $19 / 37$ & $21 / 30$ & $37 / 13$ & $22 / 6$ \\
\hline 7. & Проектний менеджмент & $0 / 6$ & $3 / 21$ & $48 / 55$ & $42 / 12$ & $7 / 6$ \\
\hline 8. & Тайм - менеджмент & $5 / 13$ & $12 / 36$ & $44 / 29$ & $47 / 19$ & $14 / 3$ \\
\hline
\end{tabular}


Продовження таблиці 1

\begin{tabular}{|c|l|c|c|c|c|c|}
\hline 1 & \multicolumn{1}{|c|}{2} & 3 & 4 & 5 & 6 & 7 \\
\hline 9. & Ініціативність і підприємливість & $3 / 9$ & $17 / 35$ & $22 / 43$ & $43 / 10$ & $15 / 3$ \\
\hline 10. & Робота у команді & $1 / 8$ & $15 / 33$ & $38 / 41$ & $41 / 16$ & $5 / 2$ \\
\hline 11. & Здатність аналізувати & $4 / 15$ & $17 / 35$ & $40 / 34$ & $26 / 13$ & $13 / 3$ \\
\hline 12. & Вміння працювати самостійно & $5 / 12$ & $12 / 27$ & $31 / 49$ & $42 / 11$ & $10 / 1$ \\
\hline 13. & $\begin{array}{l}\text { 3датність налагоджувати ефективну співпрацю } 3 \\
\text { громадою }\end{array}$ & $6 / 13$ & $22 / 34$ & $41 / 49$ & $27 / 4$ & $4 / 0$ \\
\hline 14. & $\begin{array}{l}\text { Вміння формувати бюджет школи і складати } \\
\text { кошторис }\end{array}$ & $-/ 11$ & $8 / 24$ & $39 / 55$ & $43 / 8$ & $10 / 2$ \\
\hline 15. & $\begin{array}{l}\text { Готовність перейти на самостійний } \\
\text { бухгалтерський облік }\end{array}$ & $14 / 29$ & $18 / 51$ & $38 / 17$ & $24 / 3$ & $6 / 0$ \\
\hline 16. & Демократизація управління школою & $7 / 18$ & $19 / 43$ & $32 / 24$ & $36 / 15$ & $6 / 0$ \\
\hline
\end{tabular}

Аналіз отриманих результатів дослідження показує, що директори шкіл, які пройшли навчання, продемонстрували вищі показники рівня управлінських компетентностей у порівнянні з колегами контрольних груп, що підтверджує необхідність модернізації процесу підготовки кадрового резерву керівників галузі освіти. Програми розвитку територій, які розробляються і затверджуються органами місцевого самоврядування, повинні включати розділ «Робота 3 кадрами», який передбачає системну роботу місцевої влади 3 підготовки майбутніх керівників муніципальних закладів, в т.ч. і директорів шкіл. Основними принципами підбору претендентів на керівні посади мають стати такі: добровільність вибору, що проявляється у особистій згоді кандидата бути у резерві, відкритість у проведенні відбору, прозорість інформації про претендентів, об'єктивність у оцінюванні професійних і особистісних якостей претендентів, гласність процесу відбору претендентів, системність і плановість у роботі 3 майбутніми управлінцями. Важливим фактором є відповідальність влади за якісну кадрову політику. Тому робота має базуватися на результатах аналізу кадрових потреб територій, в т. ч. і для закладів освіти, яким враховується як поточна, так і перспективна потреба у керівних кадрах. Особливої уваги потребують питання нормативно-правового забезпечення підготовки резерву керівників, зокрема розроблене і відповідно затверджене місцевим органом влади положення про роботу з кадровим резервом, яким передбачено порядок формування кадрового резерву, перелік особистих професійних критеріїв претендента для включення до складу резерву, порядок і терміни роботи з кадровим резервом (навчання, стажування, наставництво, самоосвіта тощо), порядок проведення конкурсного відбору для включення у резерв на посаду керівника муніципального закладу освіти тощо. Вищевказана робота може реалізовуватися у декілька етапів.

Перший етап є надзвичайно важливим з точки зору формування мотивації у сучасної молоді працювати у школі, оскільки галузь освіти не $\epsilon$ престижною у суспільстві. Цей етап передбачає пошук потенційних лідерів, які мають бажання пройти конкурсний відбір i працювати на посаді директора школи, базується на результатах спостереження, участі керівництва місцевої громади у заходах локального чи регіонального характеру з метою виявлення найбільш активних і небайдужих до залученої справи особистостей, проведення співбесід, вивчення громадської думки щодо потенційних керівників тощо.

Другий eman - робота з претендентами, що бажають потрапити до складу резерву управлінських кадрів, передбачає занурення у проблему освітнього менеджменту, вивчення i виявлення реальних можливостей претендентів займати посаду директора школи після обрання за конкурсом. Він має базуватися на використанні науково виважених методик діагностики, що передбачають виявлення лідерських задатків, комунікативних та організаційних якостей особистості, здібностей та вміння стратегічно мислити, здатності до інноваційного пошуку і змін, готовності до здорового ризику, неперервного навчання, вміння формувати команду і працювати в ній тощо. Використання інтерактивних методик роботи 3 персоналом (анкетування, ділові ігри, групові дискусії, тестування, опитування, завдання із розв'язання проблемних ситуацій управлінського характеру, моделювання шляхів вирішення тих чи інших управлінських проблем, вивчення портфоліо претендента, індивідуальні співбесіди тощо) сприятиме виявленню лідерського потенціалу претендентів, розкриє їхні творчі задатки, ступінь умотивованості до роботи на посаді директора школи. На цьому етапі важливим $є$ врахування вимог до компетентностей особистості 21-го ст. для різних сфер життя, що асоціюється 3 критичним мисленням, комунікацією, співпрацею, креативністю та 
інноваційністю. Другий етап кадрової роботи має завершатися формуванням і затвердженням власником складу резерву керівників для закладів місцевої комунальної власності.

Tpeтій етаn - підготовка резерву управлінських кадрів, що $є$ найбільш важливим i відповідальним у роботі з майбутніми керівниками і включає як теоретичну, так і практичну складові, передбачає розвиток управлінських компетентностей майбутнього директора школи на основі сформованих ключових і галузевих компетентностей. Для позитивного вирішення питання на цьому етапі влада на місцях має створювати умови для навчання претендентів за освітньо-кваліфікаційним рівнем «Магістр», спеціальність «Управління навчальним закладом», а саме: надавати цільові направлення на навчання і здійснювати оплату, узгоджувати графік навчання із графіком роботи (для тих, хто навчається i працює), умов оплати праці, забезпечити соціальні гарантії, враховувати потребу у часі на самоосвіту тощо. На цьому етапі важливим фактором $є$ узгодженість дій виконавчих комітетів, зокрема відділів/управлінь освіти із закладами вищої освіти, що здійснюють підготовку майбутніх директорів шкіл у частині врахування запитів і потреб як місцевого органу управління галуззю до рівня підготовки майбутнього спеціаліста, так і особистісних запитів здобувача освіти. Саме тому слід надати особливого значення не лише формам здобуття освіти, але й змістовому забезпеченню навчального процесу. Досвід закладів вищої школи США, Західної Європи і Азії показує, що сучасна молода людина $є$ досить вимогливою до поняття «свобода вибору», планування свого часу, в т. ч. й здобуття освіти, і досить ретельно обирає форми навчання. Йдеться про зміну очікувань здобувачів освіти, які вимагають систему освіти, що має більший зв'язок i релевантність з їхнім повсякденним життям [8]. На часі - широке використання не лише можливостей формальної освіти, але й неформальна та інформальної, модернізація змісту програм підготовки магістрів, які повинні відповідати сучасному баченню ролі і місця керівника школи у суспільстві, що змінюється й передбачати формування і розвиток управлінських компетентностей майбутніх директорів шкіл. Актуальність такого підходу акцентується не лише на рівні України. Проблема якості підготовки директорів шкіл носить глобальний характер, про що свідчать і роботи відомого американського дослідника А. Левіна, у яких автор стверджує, що робота директора школи транформувалася під впливом надзвичайних економічних, демографічних, технологічних і глобальних змін, розкриває виклики сучасного лідерства, аналізує стан підготовки директорів шкіл США і констатує, що освітні програми навчання керівників $\epsilon$ найслабшими 3 усіх національних освітніх програм» $[21$, c. 13-14]. Порівняння показників розвитку управлінських компетентностей директорів експериментальних і контрольних груп (табл. 1). демонструє необхідність навчання резерву, оскільки розвиток управлінських складових професійного становлення майбутнього керівника школи є надзвичайно важливим, зокрема йдеться про комунікативність, критичне мислення, вміння аналізувати і вирішувати управлінські проблеми, працювати у команді; удосконалення навичок проектного- і тайм-менеджменту; здатність налагоджувати ефективну співпрацю 3 громадами різних рівнів; подальше формування потреби у неперервному навчанні й самоосвіті. Особливої уваги потребують питання поглиблення наукових знань 3 теорії управління i освітнього менеджменту, філософії сучасної освіти, розширення знань про підприємливість i бізнес-процеси, академічної і фінансової самостійності школи, вироблення навичок проведення наукових досліджень із актуальних питань управління школою в умовах суспільних трансформацій, адміністративної реформи, демократизації суспільних процесів; навичок моніторингу і аналізу, психології спілкування, зокрема мотивації персоналу закладу освіти тощо. «У полі зору - розвиток компетентностей особистості 21-го ст., зокрема: критичне мислення і здатність вирішувати проблеми, колаборація і лідерство, спритність і адаптивність, ініціативність і підприємливість, ефективна усна і писемна комунікація, доступ та аналіз інформації, зацікавленість і уява» [22]. Свропейські дослідники С. Браукманн і П. Пашіардіс наголошують на необхідності навчання і розвитку лідерства у директорів шкіл. Таке навчання, на їхню думку, має враховувати як регіональні підходи, так і особливості країни [23, с.18-33]. Програма підготовки директорів шкіл Б. Адамса, що є складовою післядипломної освіти, дозволяє наступним поколінням керівників створювати успішні школи [24]. Унікальна онлайн програма навчання майбутніх директорів шкіл Г. Хірд, К. Селл [25]. Особливістю сучасного навчання є використання практико зорієнтованих технологій, інтерактивних форм, про що пише відомий дослідник теорії лідерства I. Оплатка: «Не дивлячись на деякий скептицизм, більшість учасників (дослідження) відзначили, що навчання на робочому місці, яке базується на теорії кар'єрного зростання, стало суттєвим внеском для їхнього професійного розвитку. Водночас курси, що були сконцентровані у значній мірі на теоріях і академічних знаннях, були 
сприйняті як менш важливі» [26, с.129-144]. Актуальними у зв’язку з територіальною реформою в Україні є твердження П. Карстан'є і Ч. Веббера щодо моделей розвитку освітнього лідерства у країнах Східної Свропи. Автори вважають, що, по-перше, моделі повинні бути адаптованими до місцевої організаційної і системної культури, по-друге, міжнародні програми розвитку лідерства повинні розкривати учасникам різні підходи до навчання i сприяти рефлексивному аналізу їх різноманітності. Розширені моделі підготовки майстер-тренерів повинні бути заплановані з самого початку проектів, щоб визначити різницю в статусі між майстер-тренерами і підготовленими тренерами [27, с.739-751]. Практична сторона підготовки має включати стажування за цільовими програмами в Україні і за кордоном, наставництво визнаних керівників - лідерів, навчальну практику на базі кращих загальноосвітніх навчальних закладів. Саме тому в 21-му ст., що є століттям інформаційних і цифрових технологій, особливого поширення набули такі форми навчання як очно - дистанційна і дистанційна, що активно використовують можливості он-лайн навчання, перевернутого навчання, відеолекції викладачів провідних світових університетів, використання індивідуальних та групових форм навчання. Форуми для обговорення ключових питань, проведення чатів і круглих столів тощо дають можливість успішно навчатися, використовуючи найбільш зручний час і найбільш зручне для слухача обладнання (комп'ютер, ноутбук, планшет, телефон).

Висновки. Аналіз літературних джерел, узагальнення отриманих даних експериментального дослідження щодо рівня сформованості управлінських компетентностей керівників закладів освіти дає підстави для висновку, що підготовка резерву керівників шкіл $є$ питанням державної ваги, вирішення якого має враховувати суспільно-політичні і соціальноекономічні трансформації в Україні, базуватися на здобутках вітчизняних вчених і результатів досліджень зарубіжних колег з питань шкільного лідерства і освітнього менеджменту, кращих вітчизняних і зарубіжних практиках. Важливим є розуміння і вирішення проблеми на рівні місцевої влади, розроблення і реалізація завдань програми розвитку територій із врахуванням кадрових проблем закладів освіти, підготовка яких має проводитися у декілька етапів. Навчання майбутніх і працюючих директорів шкіл повинно відбуватися за оновленими програмами із врахуванням кращого світового досвіду підготовки керівників шкіл, розгортання наукової дискусії щодо методологічних викликів, що стоять перед сучасним шкільним лідерством, налагодження шляхів співпраці влади і громади у вирішення проблеми підготовки резерву керівних кадрів для муніципальних закладів освіти.

\section{ЛІТЕРАТУРА}

1. 21st Century Pedagogy Retrieved from https://www.teachingenglish.org.uk/article/21st-century-pedagogy

2. Knowles M. S. The Modern Practice of Aduet Education. From Pedaqoqy to Andraqoqy. - Chicaqo, 1980.

3. Leadership Challenge: Improving learning in schools Bill Mulford Retrieved from https://research.acer.edu.au/cgi/viewcontent.cgi?article=1000\&context=aer

4. Клокар Н. І. Управлінські компетентності директора школи: сучасні тенденції/ Н. І.Клокар// Вісник Київського національного університету імені Тараса Шевченка-1(7) 2018. - С.28-32.

5. Клокар Н. І. Концептуальні засади розвитку управлінських компетентностей директорів опорних шкіл у процесі підвищення кваліфікації / Н. І.Клокар // Післядипломна освіта в Україні. - 2017. - С.3-8.

6. Клокар Н. І. Розвиток ціннісної складової громадянських компетентностей директорів шкіл у системі підвищення кваліфікації/ Н. І.Клокар //Педагогічний альманах: збірник наукових праць/ редкол. В. В.Кузьменко (голова) та ін. - Херсон: КВНЗ «Херсонська академія неперервної освіти». 2017.- Випуск 35. - С.188 - 194.

7. Клокар Н. I. Управління освітніми програмами як складова професійних компетентностей директора школи/Н.I.Клокар// Scientific Journal Virtus.- February 21.- 2018.-C.115-120.

8. 21st century competencies Retrieved from http://www.edugains.ca/resources21CL/About21stCentury/21CL_21stCenturyCompetencies.

9. 8 Common Leadership Styles Associations Now January/February 2013 Issue By: Rhea Blanken, FASAE Retrieved from http://www.asaecenter.org/resources/articles/an_magazine/ 2013/january/8-commonleadership styles.

10. 21st. Retrieved from century http:// schools.com/tony-wagner.html.

11. The Leadership Development Trends in 2018 By Melissa Lamson Retrieved https://www.linkedin.com/pulse/leadership-development-trends-2018-melissa-lamson.

12. The Leadership Challenge: Improving learning in schools Bill Mulford https://research.acer.edu.au/cgi/viewcontent.cgi?article=1000\&contextaer

13. William C. Frick A Self-Study on Preparing Future School Leaders / William C. Frick, Ann T. Riley // Journal of Research on Leadership Education August 2010, Volume 5, Number 9. 
14. The eight qualities of successful school leaders https://www.theguardian.com/teacher-network/teacherblog/2013/sep/24/eight-qualities-successful-school-leaders.

15. Pierre Tulowitzki, (2013) "Leadership and school improvement in France", Journal of Educational Administration, Vol. 51 Issue: 6, pp.812-835.

16. Paul V. Bredeson, (1987) Principally speaking: an analysis of the international communication of school principals, Journal of Educational Administration, Vol. 25 Issue: 1, pp.55-71.

17. Allan Walker, Haiyan Qian, (2006) "Beginning principals: balancing at the top of the greasy pole", Journal of Educational Administration, Vol. 44 Issue: 4, pp.297-309.

18. Stephanie Chitpin, (2014) "Principals and the professional learning community: learning to mobilize knowledge", International Journal of Educational Management, Vol. 28 Issue: 2, pp.215-229.

19. Leonard A. Valverde, (2002), School leadership for 21st-century urban communities, in Richard C. Hunter, Frank Brown (ed.) Challenges of Urban Education and Efficacy of School Reform (Advances in Educational Administration, Volume 6) Emerald Group Publishing Limited, pp.187-198.

20. Preparing a New Breed of School Principals: It's Time for Action» By Gene Bottoms, Kathy O’Neill Retrieved from http://www.wallacefoundation.org/knowledge-center/Documents/Preparing-a-New-Breedof-School-Principals.pdf.

21. Levine, A. (2005). Educating school leaders. Washington, DC: The Education Schools Project. p.13-14 Retrieved from http://edschools.org/pdf/Final313.pdf.

22. Wagner, a Harvard University innovations expert, the 21st Century skill Retrieved from http://www.21stcenturyschools.com/tony-wagner.html.

23. Stefan Brauckmann, Petros Pashiardis, (2011) "Contextual framing for school leadership training: Empirical findings from the Commonwealth Project on Leadership Assessment and Development (CoLEAD)", Journal of Management Development, Vol. 31 Issue: 1, pp.18-33.

24. Postgraduate Study in School Leadership 2015 - 2016 Prospectus Retrieved from https://circle.education/wp-content/uploads/2015/06/UTAS_Prospectus_2015.pdf

25. Dr. Gillian Heard, Karen Sell The Postgraduate Study in School Leadership Retrieved from http://circle.education/post-graduate-study-overview.

26. Izhar Oplatka, (2009) "Learning the principal's future internal career experiences in a principal preparation program", International Journal of Educational Management, Vol. 23 Issue: 2, pp.129-144.

27. Peter Karstanje, Charles F. Webber, (2008) "Programs for school principal preparation in East Europe", Journal of Educational Administration, Vol. 46 Issue: 6, pp.739-751. 